\title{
Hydrogeology of Wadi Qudaid Area, Northeast Jeddah, West Central Arabian Shield, Saudi Arabia
}

\author{
Abdullah R. Sonbul'1, Mohammed A. Sharaf', Ali A. Mesaed ${ }^{3,4}$ \\ ${ }^{1}$ Engineering and Environmental Geology Department, Faculty of Earth Sciences, King Abdulaziz University, Jeddah, Saudi Arabia \\ ${ }^{2}$ Hydrogeology Department, Faculty of Earth Sciences, King Abdulaziz University, Jeddah, Saudi Arabia \\ ${ }^{3}$ Geo-Exploration Techniques Department, Faculty of Earth Sciences, King Abdulaziz University, Jeddah, Saudi Arabia \\ ${ }^{4}$ Geology Department, Faculty of Sciences, Cairo University, Giza, Egypt \\ Email:dr.asonbul@yahoo.com, Masharaf40@hotmail.com, alimesaed@Yahoo.com
}

How to cite this paper: Sonbul, A.R., Sharaf, M.A. and Mesaed, A.A. (2017) Hydrogeology of Wadi Qudaid Area, Northeast Jeddah, West Central Arabian Shield, Saudi Arabia. Open Journal of Geology, 7, 1749-1766.

https://doi.org/10.4236/ojg.2017.712117

Received: October 23, 2017

Accepted: December 8, 2017

Published: December 11, 2017

Copyright ( 2017 by authors and Scientific Research Publishing Inc. This work is licensed under the Creative Commons Attribution International License (CC BY 4.0).

http://creativecommons.org/licenses/by/4.0/

(c) (i) Open Access

\begin{abstract}
The study area is a part of the Arabian Shield rocks of west central part of Saudi Arabia ( $150 \mathrm{~km}$ to the northeast of Jeddah). Geologically, the study area comprises five main geologic units i.e. 1) Layered basic volcanics and related volcaniclastics which are composed mainly from intercalated basalts and andesites and the related volcaniclastic derivatives, 2) Acidic volcanics and related volcaniclastics which are composed from layered and laminated dark and light acidic to intermediate igneous rocks, quartz and chert and marbles, 3) The Tertiary sedimentary succession which of volcaniclastic red beds and the intercalated clays; 5) Tertiary volcanics of Harrart, and 4) The Quaternary wadi fill deposits which are composed from friable pebble supported conglomerates, sandstones and clays. Hydrogeologically, the groundwater aquifer of Wadi Qudaid is present mainly in two main horizons i.e. i) unconfined shallow aquifer $(13-37 \mathrm{~m})$ within the well porous and permeable conglomerates of the Quaternary Wadi deposits, ii) The deep confined aquifer of the bedded tuffaceous sandstones and mudstone of the Tertiary sedimentary succession of Ash Shumaysi Formation. The water samples are analyzed for major elements i.e. $\mathrm{Ca}, \mathrm{Mg}, \mathrm{Na}, \mathrm{Cl}, \mathrm{SO}_{4}, \mathrm{HCO}_{3}$ and the results show the normal content of these elements. The study related the addition and depletion of many elements during the running trip of the groundwater from the northeast (recharge area) to the southwest (downstream) area.
\end{abstract}

\section{Keywords}

Groundwater Aquifers of Saudi Arabia, Hydrogeology of West Central Arabian shield, Wadi Qudaid 


\section{Introduction}

\subsection{General Geology and Physiography}

The study area lies within the western province of Saudi Arabia between latitudes $20^{\circ} 54^{\prime} 00^{\prime \prime}$ and $21^{\circ} 57^{\prime} 23^{\prime \prime} \mathrm{N}$ and longitudes $39^{\circ} 1709^{\prime \prime}$ and $40^{\circ} 00^{\prime} 57^{\prime \prime} \mathrm{E}$ (Figure 1). Several hydrogeological research activities were carried out in the study area since the early seventies. Most of these works were concerned with the groundwater condition, aquifer characteristics and the groundwater quality in the wadi sediments (e.g. [1]-[12]; and [13]). A few studies concerned with the trace elements concentrations such as $\mathrm{Mn}, \mathrm{Pb}, \mathrm{Si}, \mathrm{Al}, \mathrm{F}$ and $\mathrm{B}$ in the groundwater are available and outlined comprehensive investigations on groundwater condition included water chemistry within Khulais basin [14]. Detailed hydrogeological and hydrochemical studies were carried out in Wadi Usfan by [15]. Several detailed studies regarding geological and geomorphological characteristics of the area around An Numan basin are available (e.g. [16] [17] [18] [19].

The climatic conditions all over the study area may play an important role in defining the hydraulic response of the watersheds and groundwater quality existing in the region. Generally, the climate is typically arid and the rainfall is irregular and has torrential nature. The rainfall occurs during winter season, while in the autumn and spring the area is subjected to isolated events. The average annual rainfall is about $60 \mathrm{~mm}$ in the lowland areas. Where, moving towards the eastern direction the rainfall increases to more than $170 \mathrm{~mm} /$ year. Such variation in the rainfall amount can be attributed to the orographic effects of the Red Sea escarpment. Rainfall distribution over the study area was characterized in time and space. Data from the five rainfall gauges were used to establish the rainfall distribution.

The variation of rainfall in the spatial dimension reflects the topographic effects, since the highest values were recorded at the highest stations. The average monthly rainfall was computed in order to give an approximate idea of the seasonal variation in the local rainfall patterns. All effective rainfall is concentrated between November and April (with very minor exceptions in early May). Wadi Qudaid lies within the Arabian Shield rocks of the western area of Saudi Arabia. The following discussion on geology aspect will be based on the previous works available and the field observations.

Wadi Qudaid area is located N to NE of Jeddah City (about $150 \mathrm{~km}$ ) along Al Madinah asphaltic road (Figure 1). It runs in NE direction parallel to many NE trending Wadi of the west central part of Saudi Arabia i.e. Wadi Fatima, Wadi Sitarah (Figure 1(a), Figure 1(b)). The Wadi floor is filled as most of the wadies in this area by Quaternary deposits. The landforms of the Wadi area are composed mainly from Precambrian Arabia shield rocks overlained by Tertiary sedimentary rocks and harrat (Tertiary volcanic, Figure 1(b)). The wadies were formed by major NE faults and related fractures and folds (Figure 1(b)). The Precambrian rocks are intensively folded and dragged along the major NE faults 


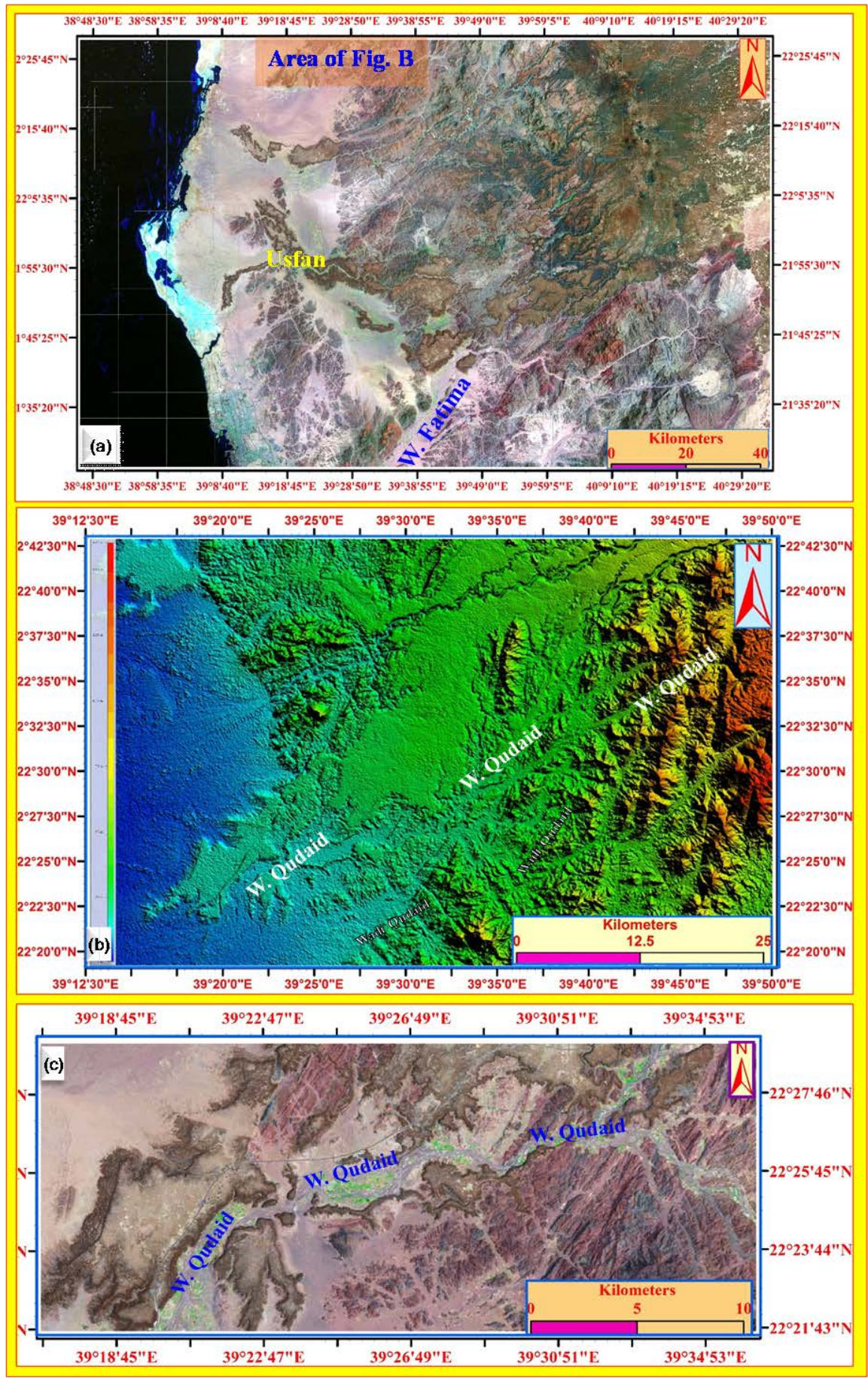

Figure 1. (a) Large-scale satellite image of the area NE of Jeddah city (Mr. Said Satellite Images of Saudi Arabia); (b) Close-up topographic satellite image of Wadi Qudaid area (World Imagery from Global Mapper (ASTER GDEM); (c) Close up satellite image of Wadi Qudaid (Mr. Said Satellite Images of Saudi Arabia).

(Figure 1(c)). Wadi Qudaid is recharged by many $\mathrm{N}$ and NE tributaries (small dendritic pattern, (Figure 1(a)). This main asphaltic road is parallel to one of these NE tributaries. The tributaries that recharge Wadi Qudaid are drained on the folded and faulted Arabian shield rocks. 
Several earlier studies (e.g. [20] and [21]) were concerned the general geology as well as the structural geology of the Arabian Shield. The most detailed study concerning the geology of the study area is that of Ramsay (1986) and Moore and Al-Rehaili (1989) and Johnson (2006). They outlined detailed studies concerning the geology of the study area. According to their works; three stratigraphic units were recognized in the study area. These are: a) Precambrian layered rocks; b) Cenozoic sedimentary rocks; c) Tertiary volcanic rocks (harrat); and c) Quaternary deposits.

\subsection{Aims of the Study}

The present study aims to shed light on the general geology and hydrogeology of Wadi Qudaid Area. The study also aims to clarify the integration between the geologic parameters and the variation in the hydrochemistry of the groundwater.

\subsection{Materials and Methods}

The study is based mainly up on the following methods of studies: 1) Detailed field work including the preparation of the geologic maps and satellite images of the study area; 2) Hydrogeologic field works including the location of the water samples, collection of the groundwater samples; 3) Geological field work including the field description of the different rock units, the sampling of the rock units, measuring stratigraphic sections and the strike and dip of the bedded strata; 4) Lab works including preparation of the water samples for chemical analyses, the megascopic description of the rock samples, selection of the samples for thin section preparation, description and photocopying of the prepared thin sections and finally 5) Office works including the description and interpretation of the different results, their integration and writing of the manuscript.

13 water samples have been collected from wells scattered all over the study area, all samples have been fully analyzed for Major constituents. The Major constituents are: $\mathrm{Ca}^{2+}, \mathrm{Mg}^{2+}, \mathrm{Na}^{+}, \mathrm{K}^{+}, \mathrm{HCO}^{3-}, \mathrm{CO}_{3}^{2-}, \mathrm{SO}_{4}^{2-}$ and $\mathrm{Cl}^{-}$. Beside the determination of pH, E.C., T.D.S and T. Hard., The results are shown in Table 1 in the Hydrochemistry section.

\subsection{Detailed Geology and Geomorphology of Wadi Qudaid Area}

The study area is a part of the Arabian shield of the west control Saudi Arabia. Generally, the study area comprises four main rock units (Figure 2), these are the Precambrian Arabian shield rocks, the Cenozoic sedimentary rocks, the Cenozoic sedimentary Basalt (Harrat) and the Quaternary sedimentary succession. These rock units are cleared in the satellite images of the study area (Figure 1(a), Figure 1(b)). The present field measurements and observations revealed the presence of the following well discriminated five rock units, these are: 1) Layered basic volcanics and related volcaniclastics (Figure 3(a), Figure 3(b)), 2) Acidic volcanics and related volcaniclastics (Figure 3(c)-(f)). These rocks were folded and faulted and truncated to different levels. 3) The Tertiary sedimentary 


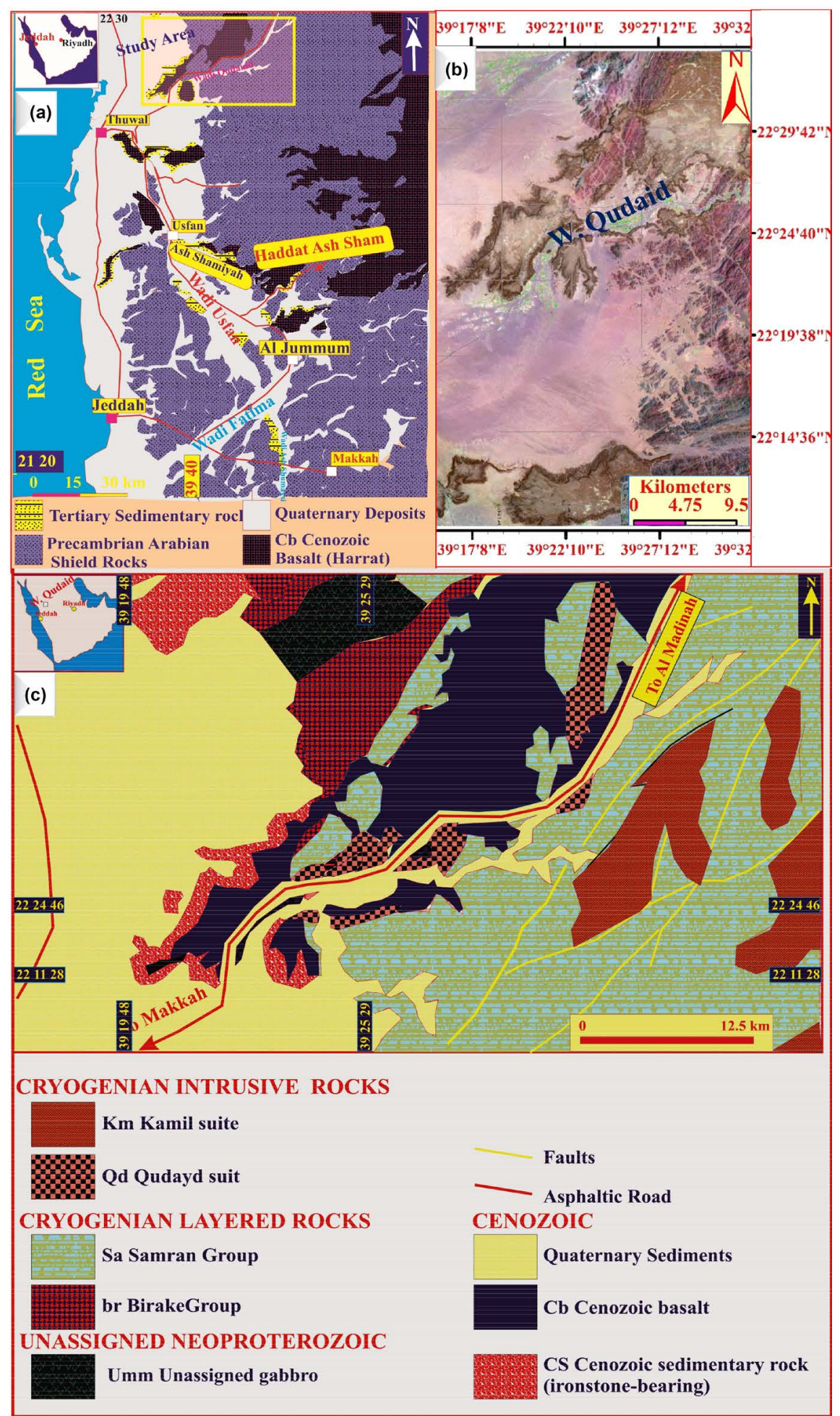

Figure 2. (a) Generalized geologic map of NE Jeddah area; (b) Drainage satellite image of Wadi Qudaid; (c) Close-up detailed geologic map of Wadi Qudaid area [22].

succession of volcaniclastic red beds and the intercalated clays (Figure 3(a), Figure 3(b)); 4) Tertiary volcanics of Harrart (Figure 3(c)), and 5) The Quaternary wadi fill deposits which are composed from friable pebble supported 


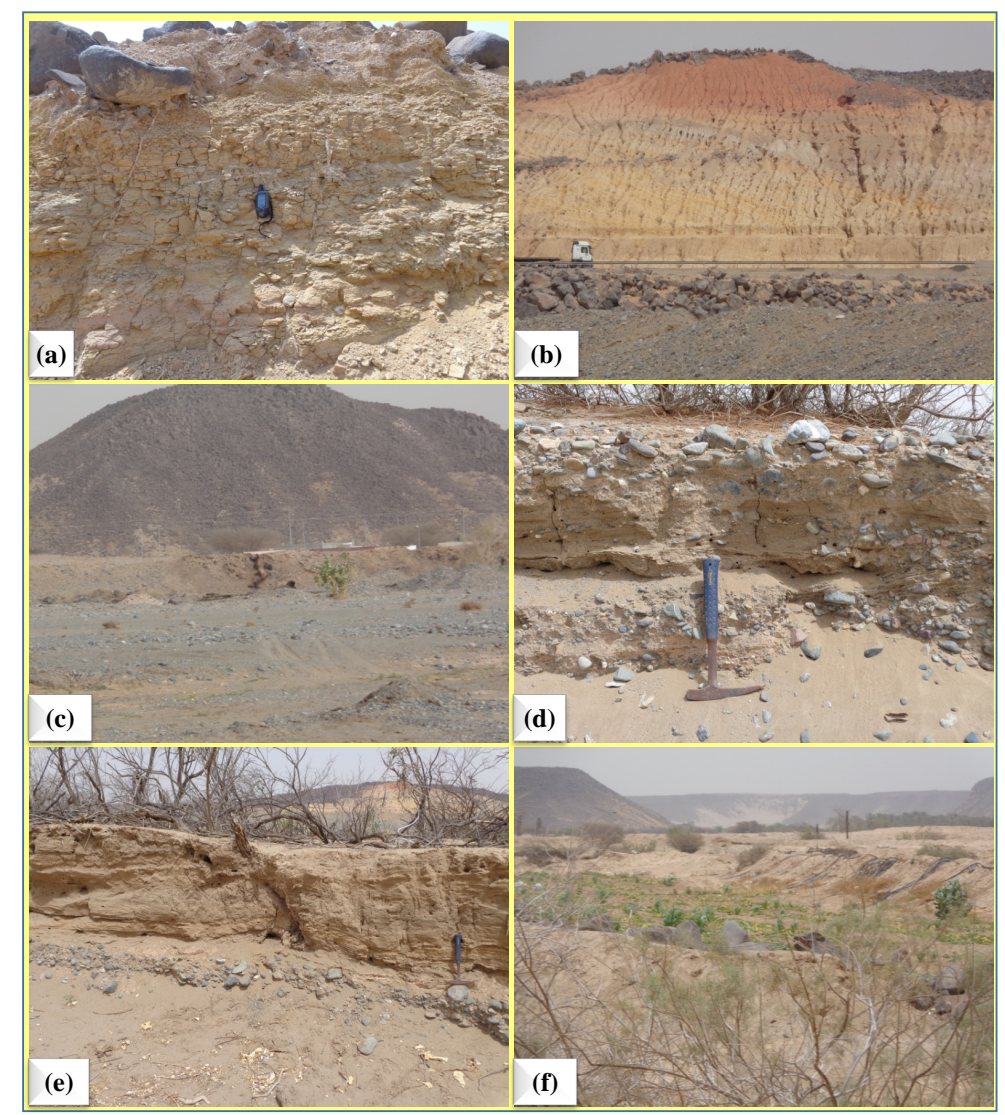

Figure 3. (a) Yellow mudstones of Ash Shumaysi Formation; (b) Volcaniclastic red beds of Ash Shumaysi Formation; (c)-(e) The Quaternary deposits of Wadi Qudaid area; (f) Cultivated lands of Wadi Qudaid area.

conglomerates, sandstones and clays (Figure 3(c)-(e)). The interplay between the structural elements and the weathering processes led to the exposure of the different rock units of the study area. Each rock unit has its own color and degree of appearance on the satellite image (Figure 1(a), Figure 1(b)).

The Quaternary deposits (groundwater aquifer) are mainly present with the main Wadi and its tributaries. Most of the private farms and drilled water well are within the fine loamy yellowish while clays (flood plain lakes) of the different sheet flood periods (Figure 3(f)). To give a good picture about the sheet flood periods and the related alluvial fan deposits of the study area, a good exposure of one big excavated quarry is presented here (Figure $3(\mathrm{~d})$, Figure $3(\mathrm{e})$ ). The succession is composed mainly from successive fining-upward cycles of lower rounded rock fragment, clast supported conglomerates which grade upwards into siltstone contains some rounded pebbles (Figure 4(e), Figure 4(f)). Graded bedding is well pronounced and load casts are also seen.

In some sections, the succession becomes bedded of well observed coarse clast-supported conglomerates and fine laminated siltstone and sandstone horizons. This succession is typically representing alluvial fan section of fining-upward cycles. The fine laminated horizon also contains sporadically distributed pebbles. 
Table 1. Major elements content of the studied water samples.

\begin{tabular}{|c|c|c|c|c|c|c|c|c|c|c|c|c|c|c|c|}
\hline $\begin{array}{c}\text { Sample } \\
\text { No. }\end{array}$ & Latitude & Longitude & $\begin{array}{l}\text { Depth to } \\
\text { water/m }\end{array}$ & $\begin{array}{c}\text { Water } \\
\text { depth/m }\end{array}$ & $\mathrm{Ca}^{2+}$ & $\mathrm{Mg}^{2+}$ & $\mathrm{Na}^{+}$ & $\mathrm{K}^{+}$ & $\mathrm{SO}_{4}^{2-}$ & $\mathrm{CO}_{3}^{-}$ & $\mathrm{HCO}_{3}^{-}$ & $\mathrm{Cl}^{-}$ & Alkalinity & $\mathrm{PH}$ & $\mathrm{EC} \mathrm{ms} / \mathrm{cm}$ \\
\hline 1 & 22.3484 & 39.3264 & 19.8 & 32 & 88.176 & 53.504 & 310 & 1.4 & 112.87 & 0 & 335.5 & 470.4 & 275.22 & 7.77 & 2.4 \\
\hline 2 & 22.3496 & 39.32889 & 17.5 & 27 & 304.608 & 169.27 & 540 & 12.64 & 179.63 & 0 & 1189 & 1402.25 & 975.78 & 8.04 & 5.72 \\
\hline 3 & 22.3632 & 39.33438 & 14 & 20 & 56.112 & 38.912 & 300 & 2.19 & 108.55 & 0 & 390 & 337.3 & 320.26 & 8.04 & 2.38 \\
\hline 5 & 22.3531 & 39.30653 & 14.2 & 21 & 360.72 & 102.144 & 446 & 4.5 & 617 & 0 & 305 & 958 & 250.2 & 6.91 & 4.85 \\
\hline 6 & 22.2723 & 39.34372 & 21.4 & 28 & 128.256 & 58.368 & 255.2 & 12.38 & 110 & 0 & 793 & 391 & 650.52 & 7.85 & 2.6 \\
\hline 7 & 22.3766 & 39.34602 & 27 & 37 & 120.24 & 77.824 & 311 & 3.9 & 125.84 & 0 & 336.11 & 550.3 & 275.72 & 7.72 & 2.72 \\
\hline 8 & 22.3949 & 39.3547 & 27.5 & 30.8 & 152.304 & 97.28 & 386 & 10.5 & 303 & 0 & 884.5 & 701.12 & 725.58 & 7.48 & 3.6 \\
\hline 10 & 22.405 & 39.36417 & 24.8 & 31 & 56.192 & 29.135 & 180 & 3.4 & 101 & 0 & 153.12 & 177.677 & 125.6 & 7.56 & 1.3 \\
\hline 11 & 22.412 & 39.37632 & 46 & 56 & 212.424 & 138.624 & 370 & 8.3 & 691 & 0 & 336.72 & 763.18 & 276.22 & 7.55 & 3.77 \\
\hline 12 & 22.4134 & 39.387 & 36.5 & 62 & 168.336 & 107.008 & 420 & 7.6 & 442.5 & 0 & 293.105 & 621.23 & 240.44 & 7.92 & 3.39 \\
\hline 13 & 22.415 & 39.39456 & 16.23 & 23 & 184.368 & 46.208 & 476 & 8.6 & 560 & 0 & 308.3 & 744.711 & 252.7 & 7.93 & 3.66 \\
\hline
\end{tabular}

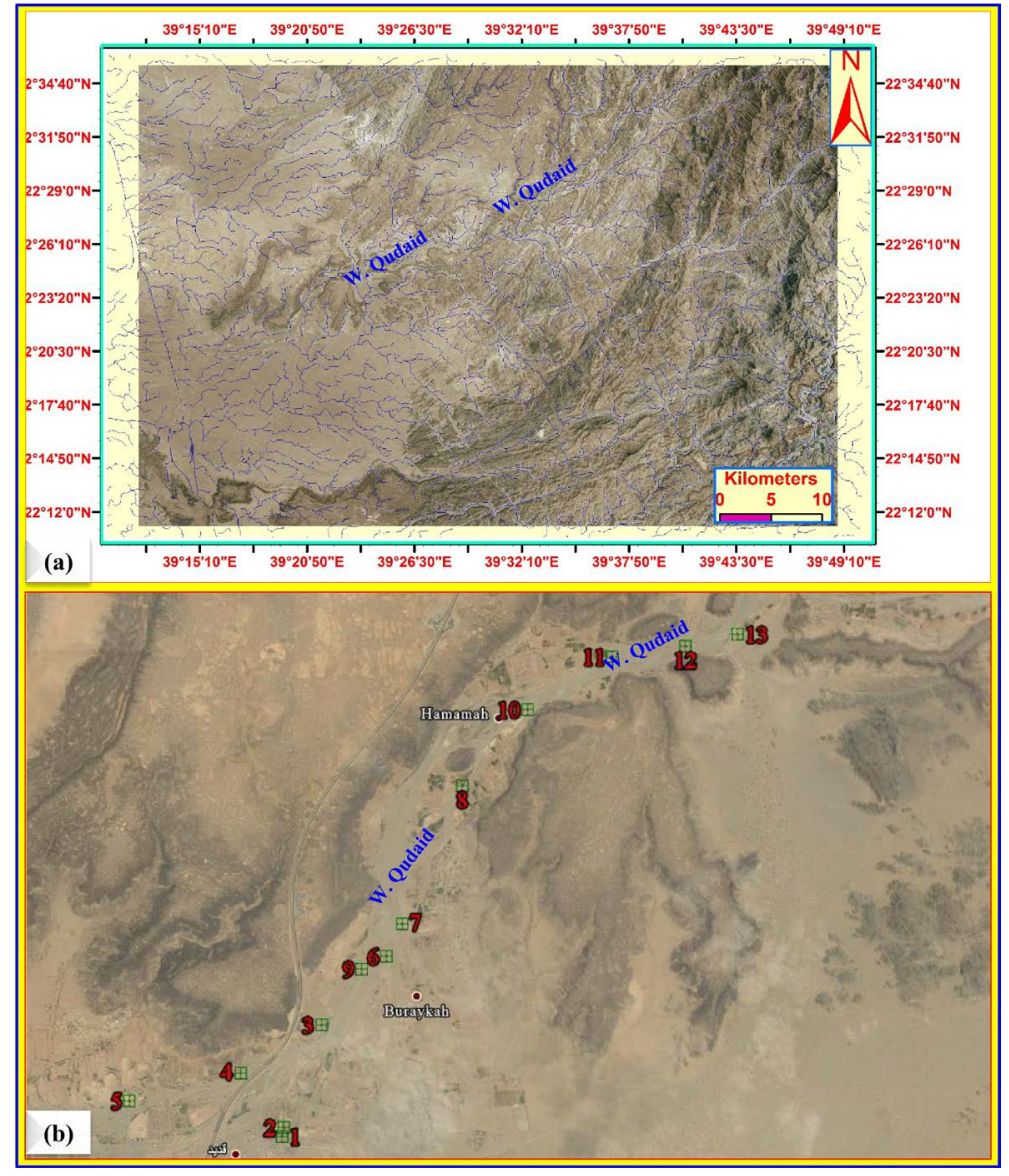

Figure 4. (a) Detailed drainage satellite image of Wadi Qudaid (World Imagery from Global Mapper); (b) Google image showing the location of the studied groundwater samples. 
From the sedimentologic points of views, the succession is of typical alluvial fan. The conglomerates of the successive fining-upward cycles are slightly disorganized which indicates its proximal position within the site of deposition and it also indicates rapid sedimentation.

Towards, the upper part of the succession, the section become finer and composed mainly from thick laminated fine sandstone/mudstone alternated with one clast thick thin beds (Figure 3(a)). Also, the thin conglomerate beds become of finer size (Figure 3(f)). In the uppermost part of the section, the cycles become wholly of thin laminated siltstone/mudstone (Figure 3(f)). Some sporadically distributed pebbles are still present.

\section{Hydrogeology of Wadi Qudaid}

The drainage lines of Wadi Qudaid area are shown in Figure 4(a). This figure shows the subparallel to dendritic network of the drainage network of Wadi Qudaid. The area is characterized by very dense small tributaries the run mostly in northeast direction and coalesced together in subparallel large drainage lines. The study is based on the collected 13 water samples from the wells of the private farms of Wadi Qudaid area (Figure 4(b)). The most common type of well construction in the area is the large diameter dug well and they are generally round in design with an average diameter of 2 meters. On the other hand, some wells are dug wholly or in part by hand, a more common method in alluvium wells is to dig a large pit using a mechanical back-hoe, to install a lining of large diameter concrete pipe sections, and then to back-fill the pit around the well. The thickness of sediments ranges from 20 to more than 48 meters in the downstream area around site 3 with an average of about 30 meters. In the middle part, the thickness ranges between 25 to 37 meters. The depth of water level from the ground surface ranges between 10 meters to 16 meters. On its upper reaches of the basin, the annual average rainfall is about $110 \mathrm{~mm}$. The rainfall season is from November to February. December to January receive nearly about $70 \%$ of the annual rainfall. During the rest of year, the rainfall is limited to isolated events. The lower reaches of the basin are among the driest parts in the region, with average rainfall not exceeding $60 \mathrm{~mm}$. In this paper, the downstream part of Wadi Qudaid basin was selected as a pilot area for the present work. An attempt was made to identify factors responsible for the groundwater chemistry variations in the shallow alluvial aquifer.

The Quaternary deposits of the study area represent superimposed alluvial fan deposits formed during progressive humid climate periods. The lower and middle parts of these alluvial fan deposits are composed from clast- and matrixsupported conglomerates overlained by cross-bedded and cross-laminated sandstones and siltstones. The distal facies of the alluvial fans are composed from massive and bedded silts and clay deposits. During the different flooding periods, the deposited alluvial material become removed and reworked and redeposited in new areas which led to the desertification and destruction of the private 
farms of the different villages of Wadi Qudaid area.

The penetrated well of the study area are present in three main rock units: a) some wells are shallow and the bottom of the wells are within the Quaternary alluvial deposits. b) Most of the wells are penetrated within the Quaternary deposits and the underlying Tertiary red beds of Ash Shumaysi Formation. The microscopic description of the yellowish white staff extracted around the well walls revealed its composition from tuffaceous sandstone of angular to subrounded quartz grains embedded in chloritized tuffaceous materials hematitized in parts (Figure 5(a)). The quartz grains show progressive and subsequent stages of corrosion and replacement by the enclosing tuffaceous matrix. Dark hematitized tuffaceous basaltic fragments are present embedded within the tuffaceous matrix (Figure 5(b)), and Figure 5(c)).

Some wells are penetrated within the hard and generally green metavolcanics of Samran Group. The field and microscopic description of the samples revealed its composition from metavolcanics, tuffs and volcanogenic massive sulphides in intermediate tuffs and andesitic tuffs (Figure 5(c)). Successive cycles from basic talcotized sulphides-free tuffs (Figure 5(d), Figure 5(e)) to intermediate devitrified sulphide-rich tuffaceous bands are recorded (Figure 5(f)).

\section{Hydrochemistry of the Groundwater of Wadi Qudaid}

The water samples are collected from the aforementioned wells (Figure 4(a)). The wells are selected from the downstream part of the wadi to compare easily between the geochemical characters of these wells. The results of the chemical analyses of the groundwater samples are shown in Table 1 . This table also includes many important data i.e. depth to water, water depth, alkalinity, $\mathrm{pH}$ and $\mathrm{EC} / \mathrm{ms} / \mathrm{Cm}$. In the field, the physical properties were measured i.e. $\mathrm{pH}$, $\mathrm{EC} / \mathrm{ms} / \mathrm{Cm}$. The locations of the water wells are also registered by GPS. The Ca, $\mathrm{Mg}, \mathrm{Na}, \mathrm{SO}_{4}, \mathrm{CO}_{3}, \mathrm{HCO}_{3}, \mathrm{Cl}$ and alkalinity were analyzed (Table 1).

\subsection{Variation Diagrams}

The plotting of the data on variation diagrams revealed that: The Ca content of the different water samples (Figure 6(a)) revealed that, the water sample of wells No. 1, 3 area of the lowest Ca content. Also, the wells No, 4, 5 are also of low Ca content. The wells of the downstream part are of high Ca content. This revealed the low Ca content of the downstream part of Wadi Qudaid. Figure 6(b) shows the Mg distribution within the studied water sample. The wells of the downstream part are of high $\mathrm{Mg}$ content. The well of the upstream (wells 11, 12, 13) are of low Mg content. Figure 6(c) shows the distribution of $\mathrm{Na}$ in the studied water wells. There is no certain trend of distribution of $\mathrm{Mg}$ in the studied water samples. Figure $6(\mathrm{~d})$ shows the distribution of $\mathrm{K}$ in the studied water samples. The samples are located in two main domains. Some samples are of low $\mathrm{K}$ content (less than 45 while other samples are of higher 7.5 to $2.5 \mathrm{~K} \%$ well 11, 12, 13 are of high $\mathrm{K}$ content. 

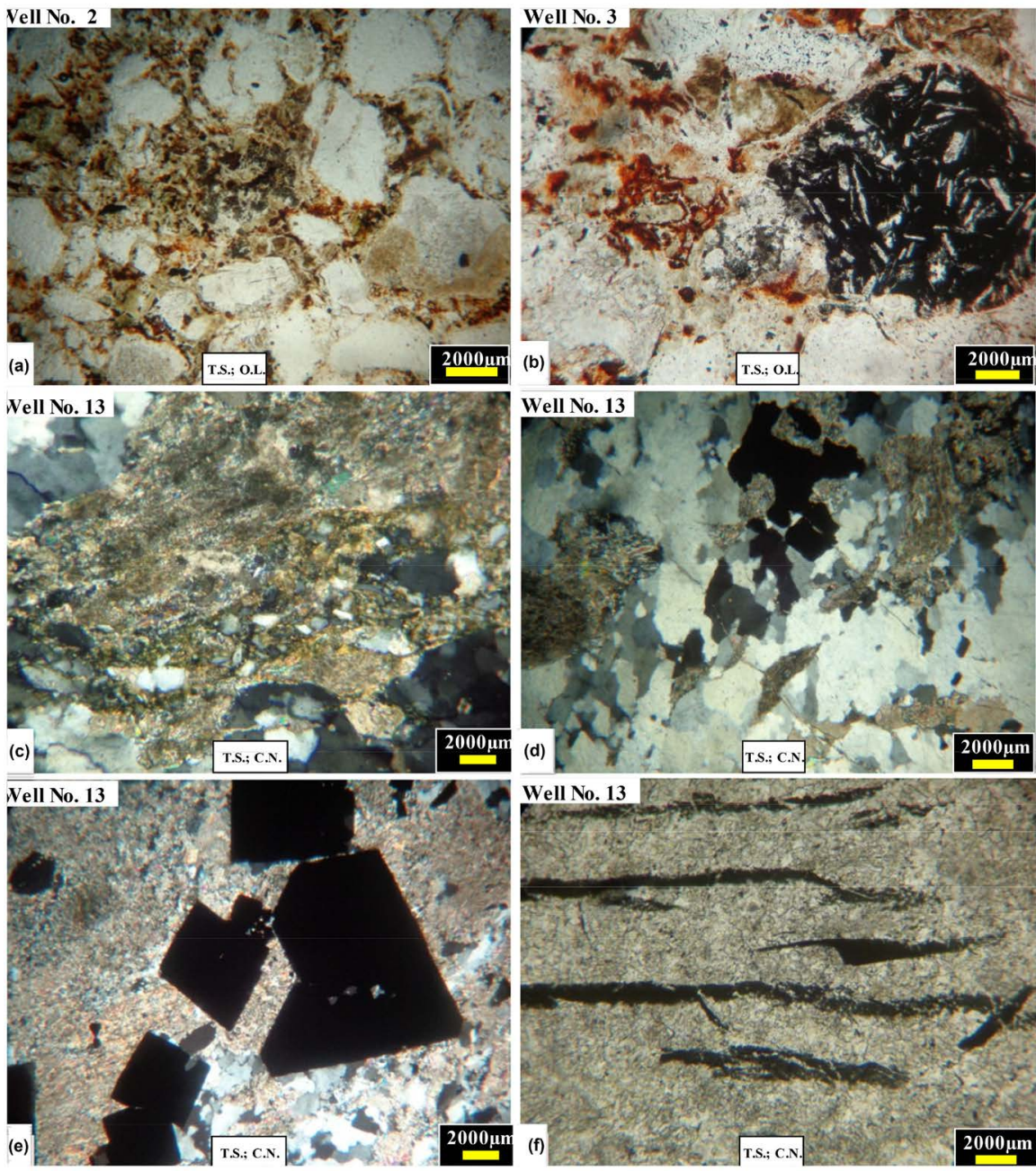

Figure 5. (a) = The microscopic description of the yellowish white staff revealed its composite-on from tuffaceous sandstone of angular to subrounded quartz grains embedded in chloritized tuffaceous materials hematitized in parts; (b) = Dark hematitized tuffaceous basaltic fragments are present embedded within the tuffaceous matrix; (c)-(f) = the water-bearing horizon of well No. 13 is composed from successive cycles from basic talcotized sulphides-free tuffs to intermediate devitrified sulphide-rich tuffaceous bands are recorded.

The distribution of $\mathrm{SO}_{4}$ within the different water samples (Figure $7(\mathrm{a})$ ) shows the low $\mathrm{SO}_{4}$ content of the wells of the downstream parts (wells No. 1, 2, $3,7)$ and its high content in wells No, 4, 7, 9, 11, 12, 13 in the upstream part of Wadi Qudaid area. The bicarbonate content $\left(\mathrm{HCO}_{3}\right)$ of the water samples of Wadi Qudaid (Figure 7(b)) revealed the mean average of $\mathrm{HCO}_{3}$ between 200 to $400 \mathrm{mg} / \mathrm{l}$ except 3 well (No. 2, 6, 8) which are slightly of high $\mathrm{HCO}_{3}$ content. The distribution of $\mathrm{Cl}$ content (Figure $7(\mathrm{c})$ ) show that, most of the water well are nearly of the same $\mathrm{Cl}$ content except well No. 10 which is of the lowest $\mathrm{Cl}$ content $(177.677 \mathrm{mg} / \mathrm{l})$. Another three well are of extreme high $\mathrm{Cl}$ content relative to the other Wadies, these are wells No. $2(1402.25 \mathrm{mg} / \mathrm{l})$ well No. $5(958 \mathrm{mg} / \mathrm{l})$ and well No. $9(1411.12 \mathrm{mg} / \mathrm{l})$. The alkalinity of the studies water samples 

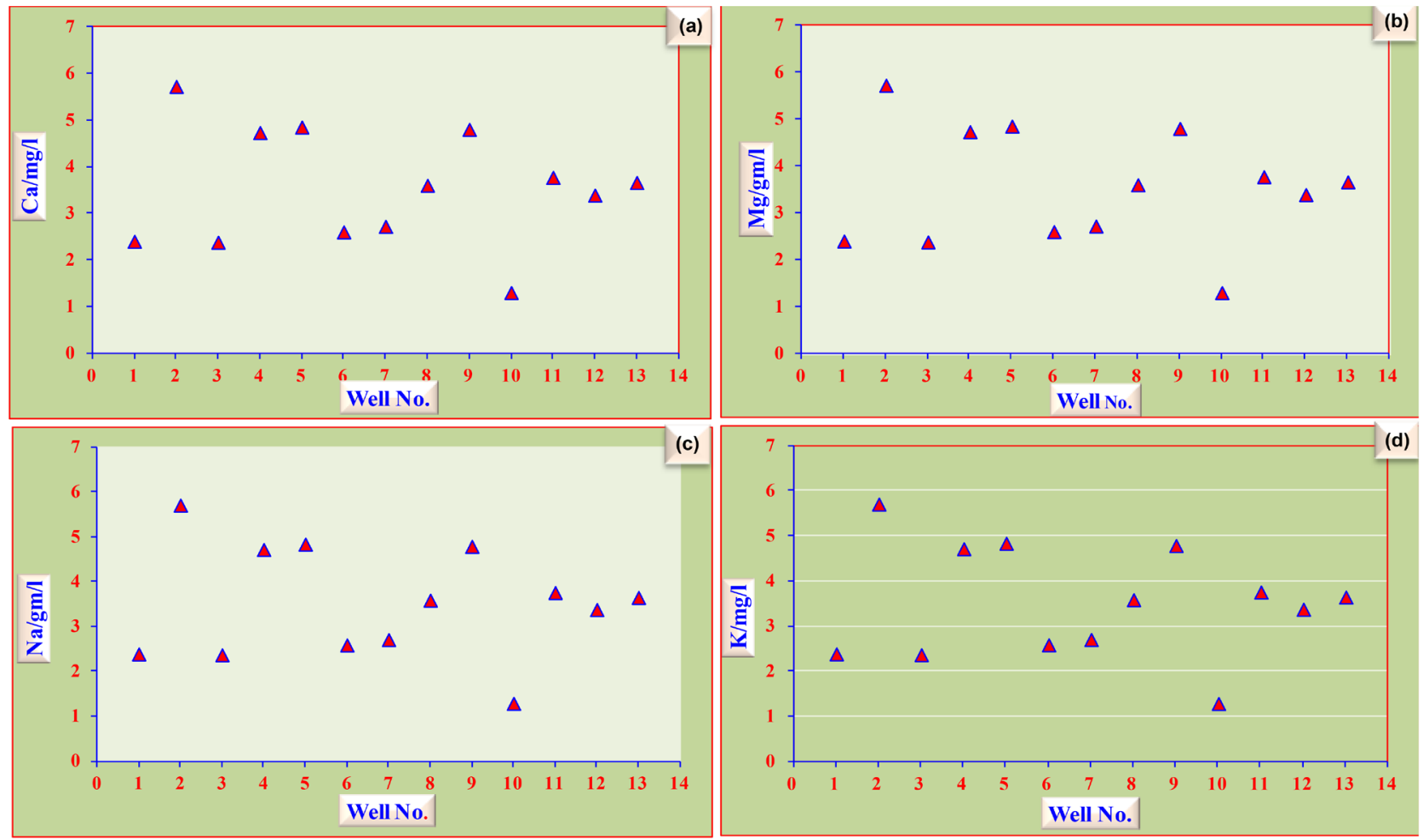

Figure 6. (a) Shows the Ca distribution of the different wells; (b) Shows the Mg distribution within the studied water sample; (c) Shows the distribution of $\mathrm{Na}$ in the studied water wells; (d) Shows the distribution of $\mathrm{K}$ in the studied water samples.
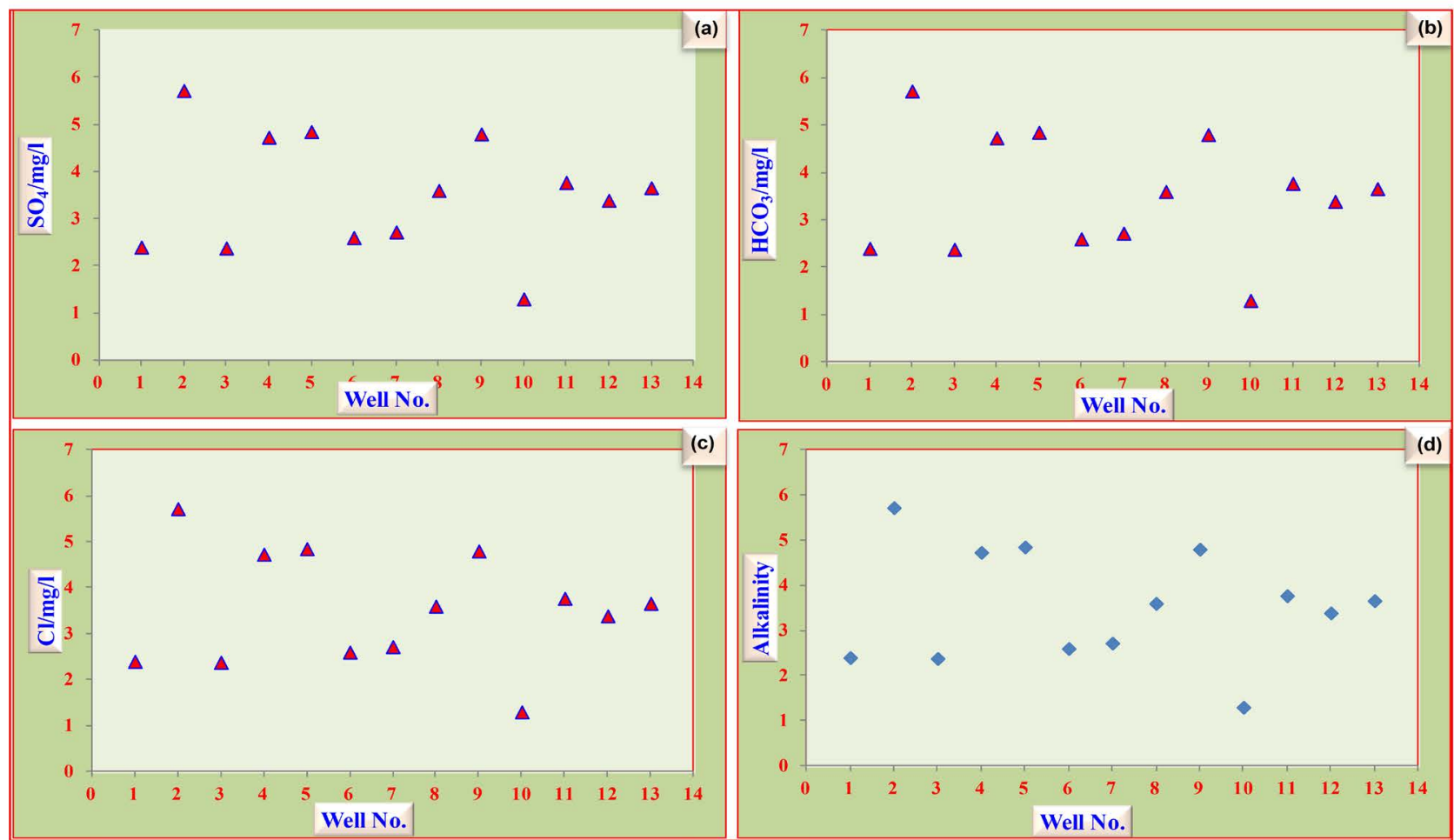

Figure 7. (a) Shows the distribution of $\mathrm{SO}_{4}$ within the different water samples; (b) Shows the distribution of $\mathrm{HCO}_{3}$ of the water samples of Wadi Qudaid; (c) Shows the distribution of $\mathrm{Cl}$ of the different wells; (d) Shows the distribution of the alkalinity within the different wells. 
(Figure $7(\mathrm{~d})$ ) show positive correlation with the bicarbonate content (Figure 7 (b)). The values of the alkalinity are mainly controlled by the $\mathrm{HCO}_{3}$. It ranges between $(200$ and $400 \mathrm{mg} / \mathrm{l})$ except wells No. $(2,6,8)$ variation in $\mathrm{pH}$.

It is evident that, the $\mathrm{pH}$ distribution of the water samples (Figure 8(a)). Most of the groundwater samples are of $\mathrm{pH}$ ranges between (7.4 and 8) except the water of well No. $5(6 \mathrm{mg} / \mathrm{l})$. Wells No. 2, 3 are of slightly higher $\mathrm{pH}$ valves (8.04 and 8.04 respectively).

\subsection{The Variation in EC $(\mathrm{EC} / \mathrm{ms} / \mathrm{Cm})$}

The electro conductivity of the groundwater samples (Figure 8(b)) revealed that, most of the groundwater samples have EC between 2 and 6 except well No. 10 (EC value 1.3). It is also observed that, that wells of the downstream are of high EC values than those of the upstream wells No. 2 has the highest EC value (5.72). The plotting $\mathrm{Ca}$ and $\mathrm{Mg}$ show positive relation which support dolomite dissolution (Figure $8(\mathrm{c})$ ). The present of dolomitic tuff within the Tertiary aquifer may be the most problem source of $\mathrm{Mg}$. Mg may also come from the basic tuffs and the ferro-magnesian minerals of the basic volcanics and related volcaniclastic rock unit.

\subsubsection{Na vs $\mathrm{Cl}$}

The plotting of $\mathrm{Na}$ against $\mathrm{Cl}$ also shows a positive relation (Figure 8(d)) revealed the positive correlation between $\mathrm{Na}$ and $\mathrm{Cl}$ which indicate salt dissolution and increasing of $\mathrm{Na}$ and $\mathrm{Cl}$ content.

\subsubsection{Ca vs $\mathrm{SO}_{4}$}

The plotting of $\mathrm{Ca}$ against $\mathrm{SO}_{4}$ show somehow positive relation which support gypsum dissolution and releasing of $\mathrm{Ca}$ and $\mathrm{SO}_{4}$ (Figure 9(a)). The plotting of $\mathrm{Ca}$ against $\mathrm{HCO}_{3}$ show no trend (Figure 9(b)). Figure 9(a) show the distribution of $\mathrm{Ca}$ in the different wells. Figure 9 (c) show the positive relationship between $\mathrm{SO}_{4}$ and EC. Figure 9(d) show the average depth to water in the different water wells of the study area.

\subsubsection{Durov, Trilinear and TDS and SAR Diagrams}

The durov diagram show the dominant water type in Wadi Qudaid area in $\mathrm{Na} \mathrm{Cl}$ type where the dominant cation is $\mathrm{Na}$ and the dominant anion is $\mathrm{Cl}$ (Figure 10). Trilinear diagram (Figure 11) also shows the $\mathrm{NaCl}$ water type of Wadi Qudaid area. The geochemical analysis of [23] also confirms the $\mathrm{NaCl}$ water type. $\mathrm{He}$ also detects the high $\mathrm{NO}_{3}$ in the groundwater of Wadi Qudaid area and related these high values to the seepage of $\mathrm{NO}_{3}$ as a result to the using nitrates as fertilizers used in the private farms. There is a negative correlation between anions $\left(\mathrm{SO}_{4}, \mathrm{Cl}\right)$ and cations $(\mathrm{Na}, \mathrm{K})$ (Figure 12). Also, there is some positive relation between TDS and SAR (Figure 13). Finally, there is a strong relation between total hardness and sum of cations (Figure 14). 


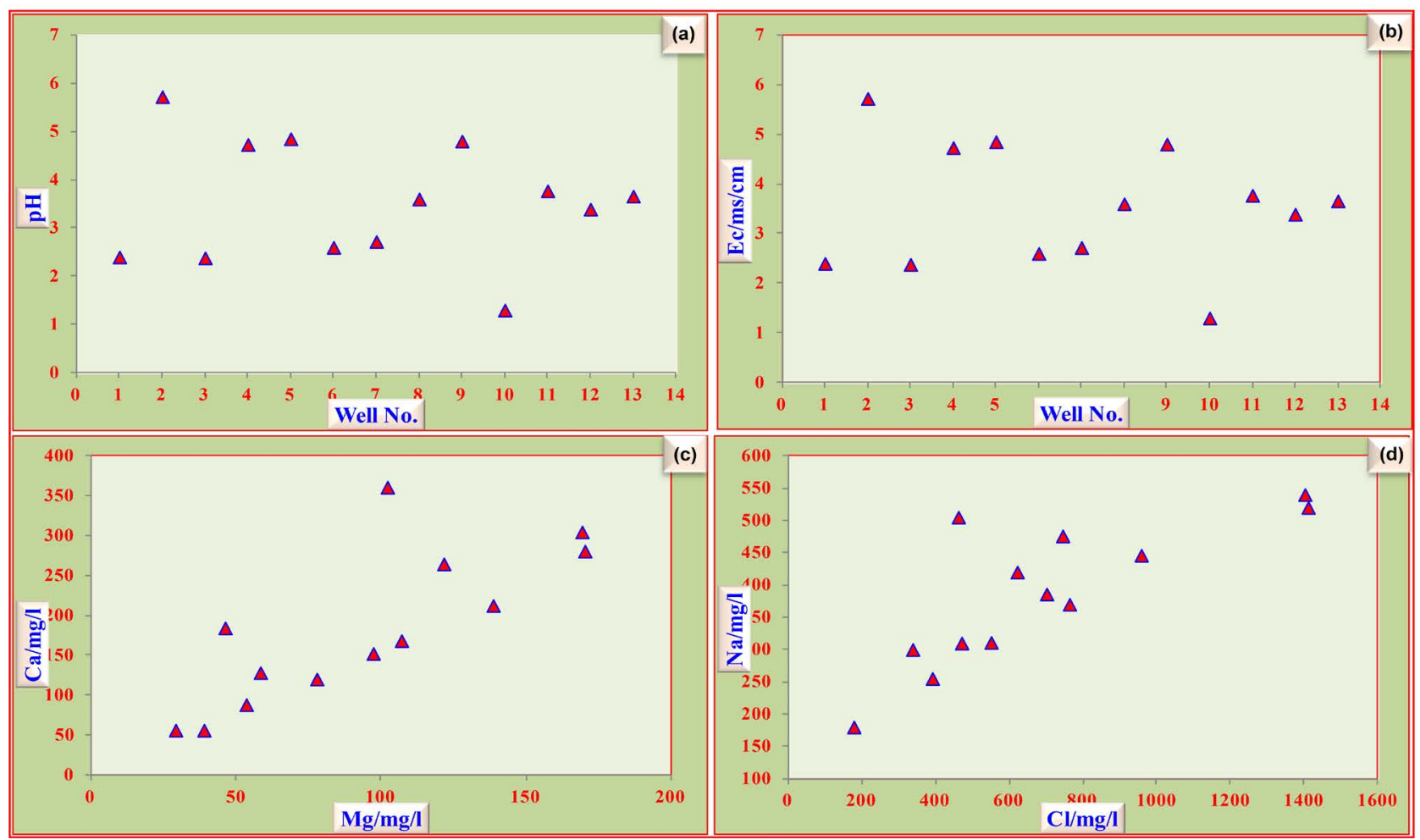

Figure 8. (a) Shows the $\mathrm{pH}$ distribution of the different water samples; (b) Shows the electro conductivity of the groundwater samples; (c) Shows the positive relation between $\mathrm{Ca}$ and $\mathrm{Mg}$; (d) Shows a positive relation between $\mathrm{Na}$ and $\mathrm{Cl}$.
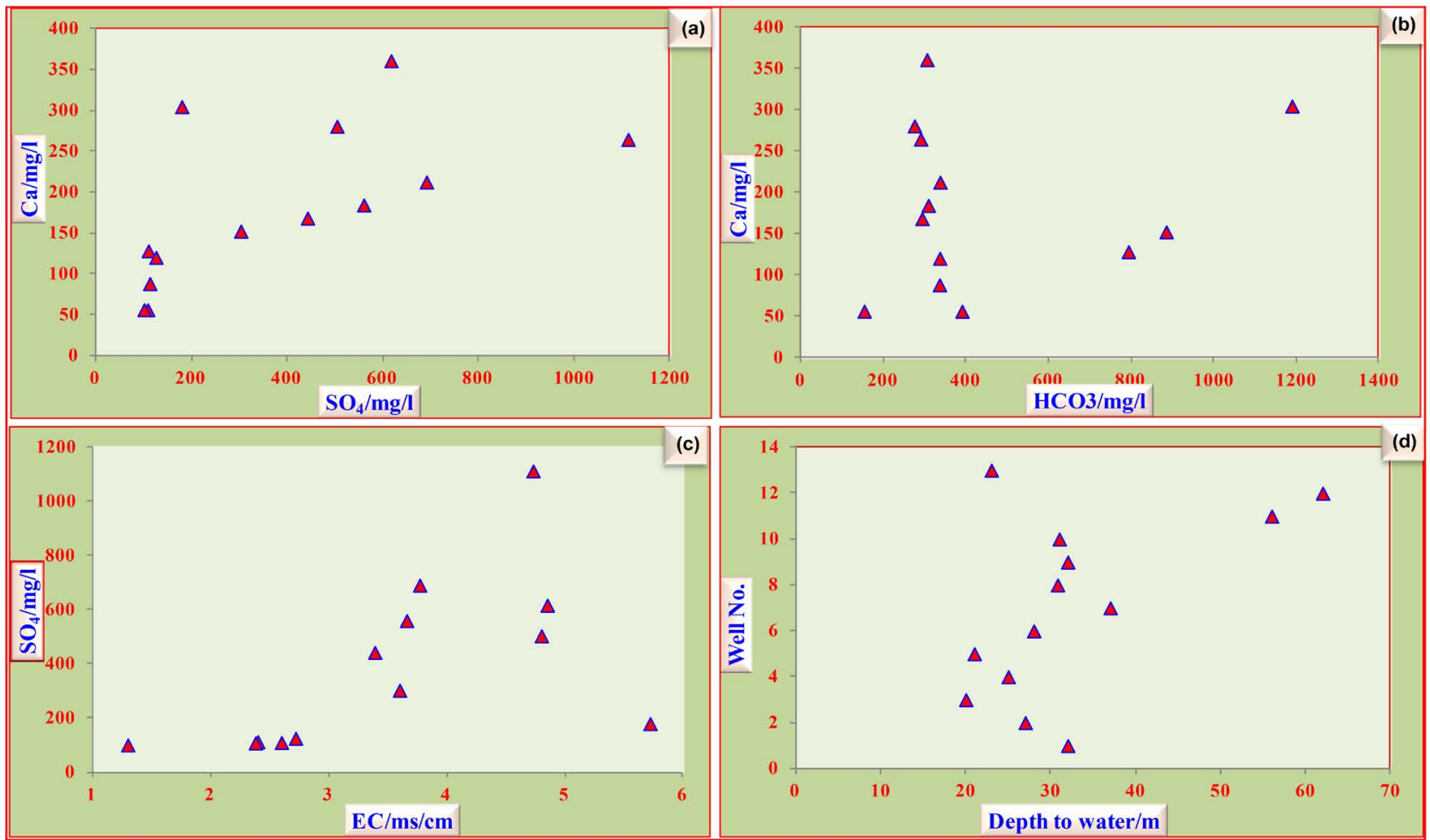

Figure 9. (a) Shows the positive relation between $\mathrm{Ca}$ and $\mathrm{SO}_{4}$; (b) Shows the absence of trend between $\mathrm{Ca}$ and $\mathrm{HCO}_{3}$; (c) $\mathrm{Shows}$ the positive relationship between $\mathrm{SO}_{4}$ and EC; (d) Show the average depth to water in the different water wells of the study area. 


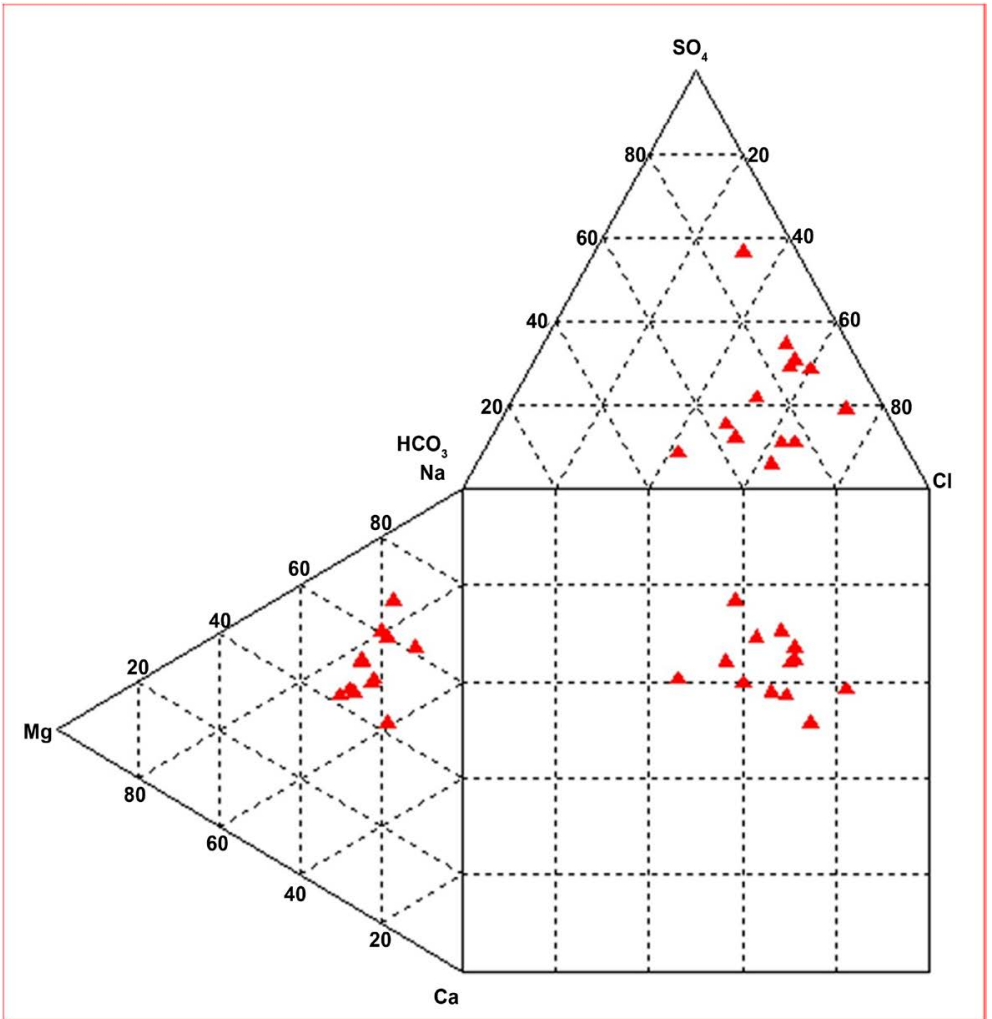

Figure 10. Durov diagram show the dominant water type in Wadi Qudaid area in $\mathrm{Na} \mathrm{Cl}$ type.

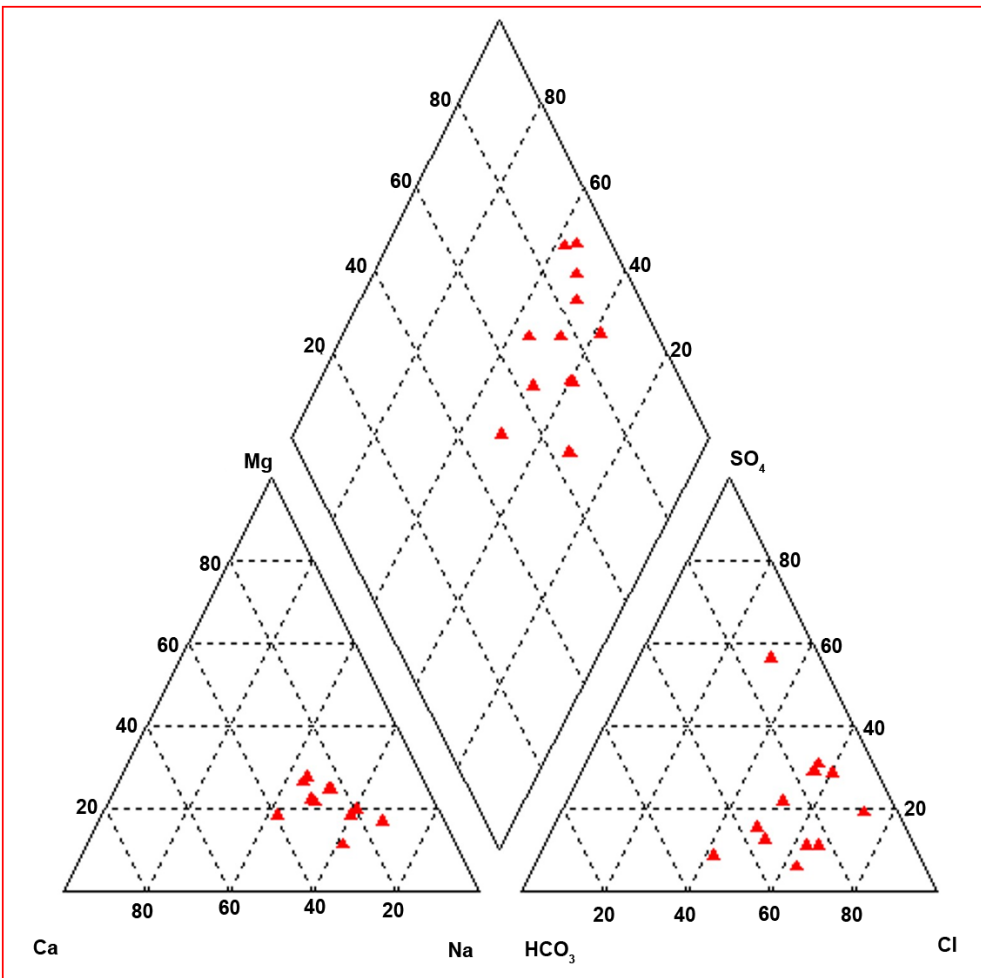

Figure 11. Trilinear diagram shows the $\mathrm{NaCl}$ water type of Wadi Qudaid area. 


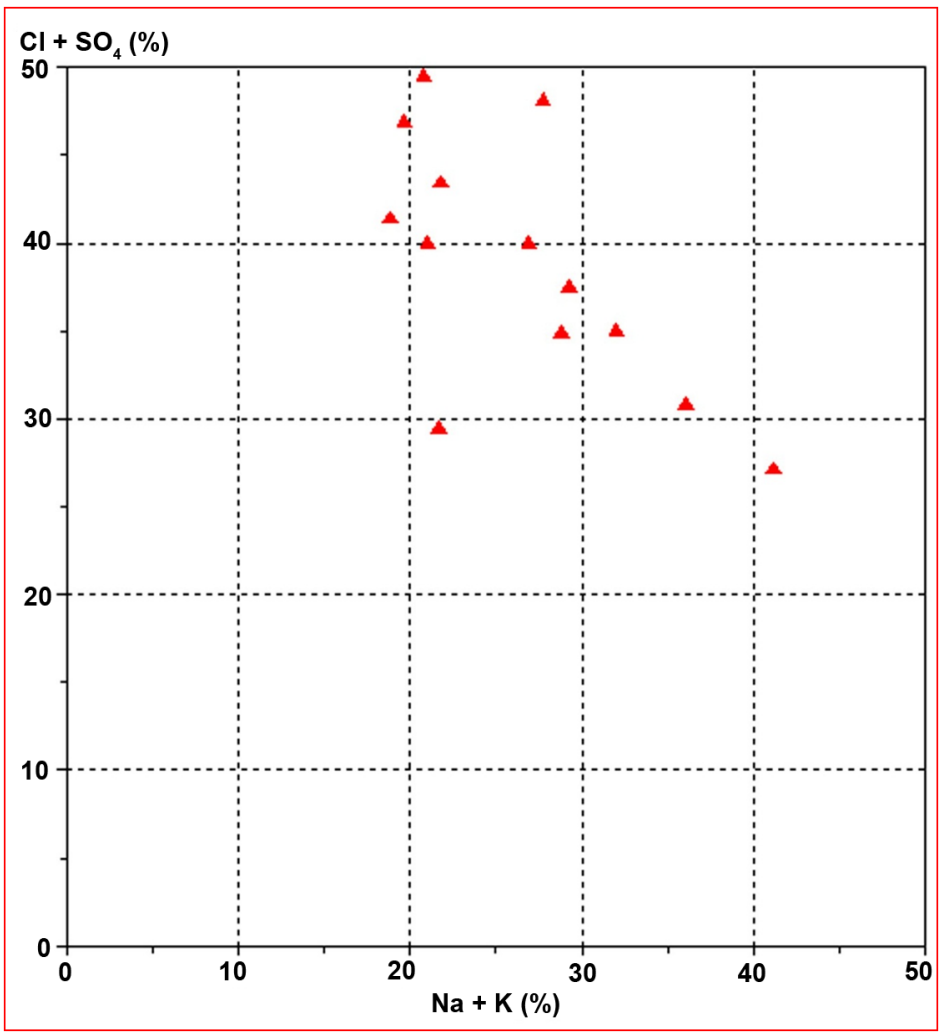

Figure 12. The negative correlation between the anions $\left(\mathrm{SO}_{4}, \mathrm{Cl}\right)$ and the cations $(\mathrm{Na}, \mathrm{K})$.

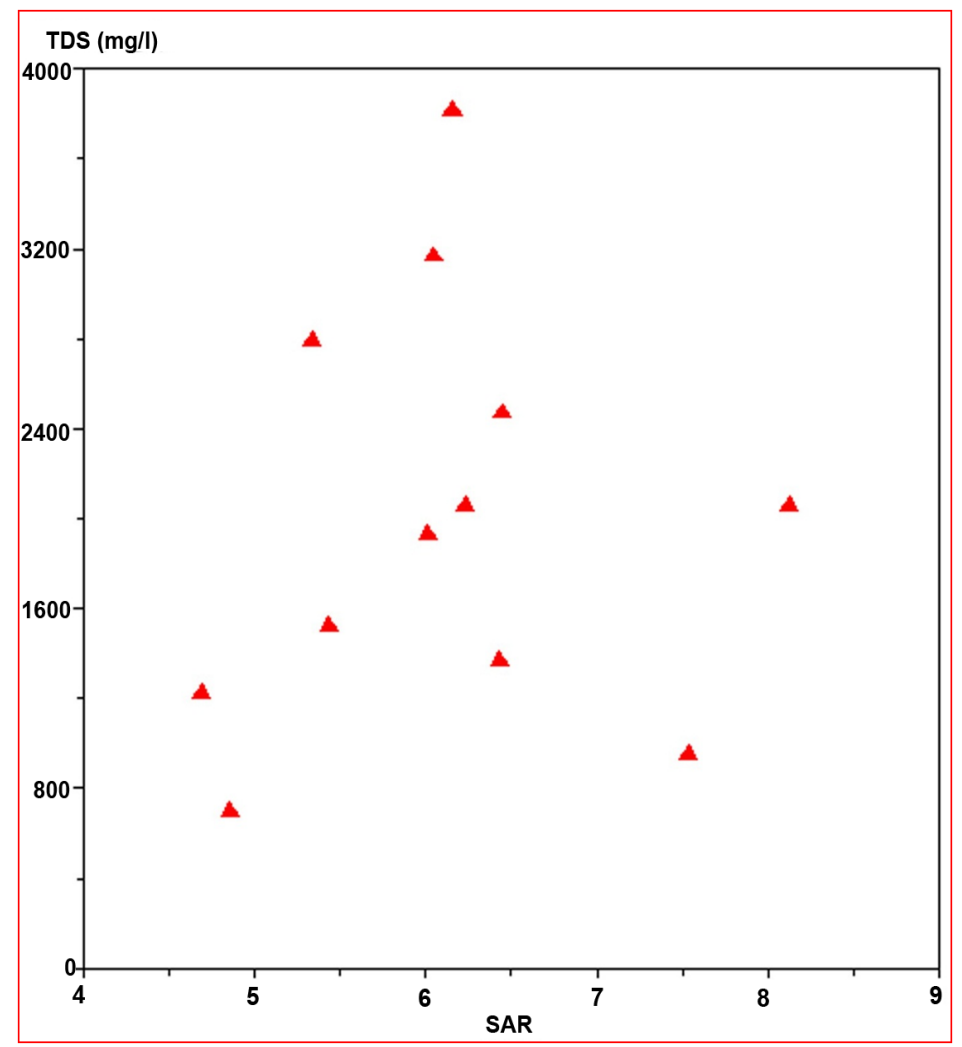

Figure 13. Positive relation between TDS and SAR. 


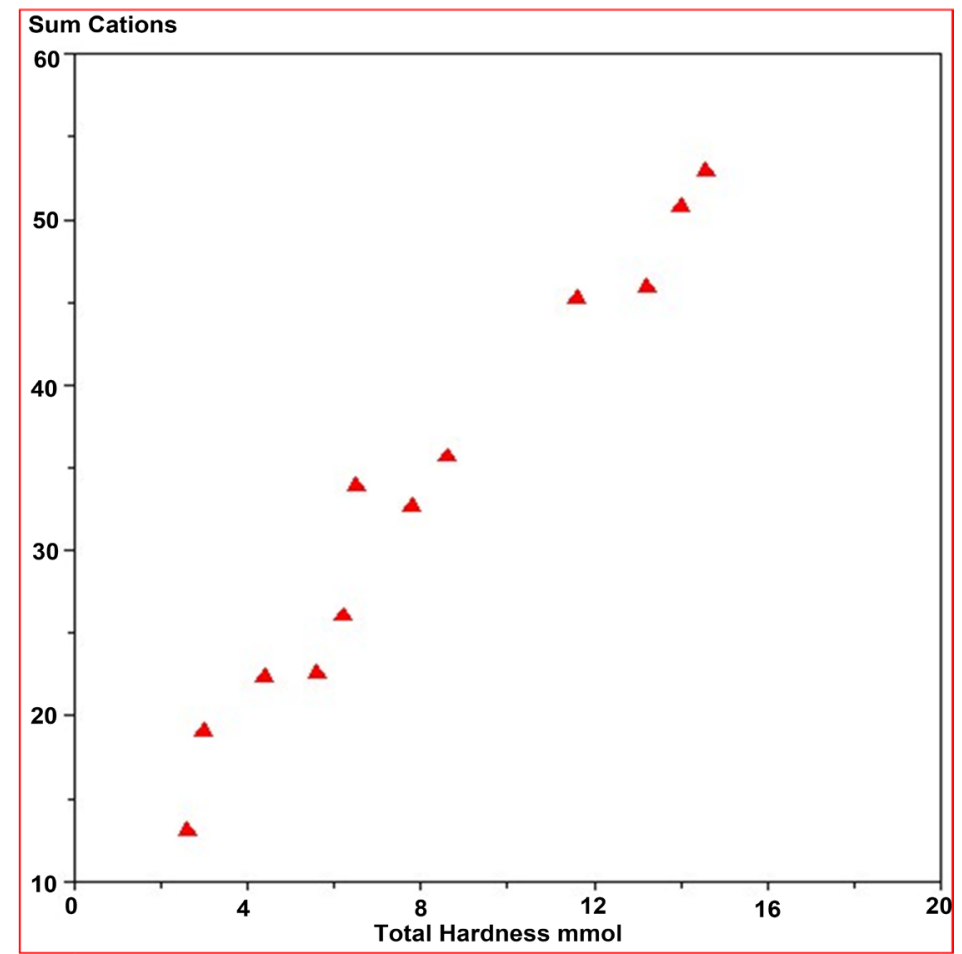

Figure 14. Strong relation between total hardness and sum of cations.

\section{Discussion}

The present study revealed that, the groundwater of W. Qudaid area is present in two main horizons: a) Quaternary alluvial gravels, conglomerates and sandstones, b) The Tertiary succession that composed from highly weathered basalts (harrat) and the underlying red ferruginous sandstones and clays of Usfan and Khulays formations. The recharge area of Wadi Qudaid is represented by the high mountainous Arabian shield rocks of the north and northeastern part of Wadi Qudaid.

The Quaternary groundwater aquifer of Wadi Qudaid area is represented by the wadi deposits of the main course and the tributaries of the wadi. These deposits are composed from successive fining-upward cycle of clast-and matrix-supported conglomerates, pebbly sandstones, siltstones and flood plain clays and represent successive alluvial fan sedimentation during the humid and arid periods. The low lands of Wadi Qudaid area represent downthrown faulted blocks where the drilled wells begin by Quaternary wadi deposit, black basalts, clastic sedimentary rocks and finally layered igneous rocks at the base of the wells. The groundwater bearing horizons varied according to the level of erosion and denudation processes where some water wells produce from the Quaternary deposits while other produce from the clastic sedimentary rocks and small number of wells produce from the layered igneous rocks. The present study revealed the presence of very clear relationship between the geology of the study area and the chemistry of the ground waters. The ground water quality appears very good and normal level for irrigation purposes. 


\section{Conclusion}

Wadi Qudaid area represents one of the main NE trending wadies in the west central part of Saudi Arabia. It represents a good exposure site for the different rock units of this part of the Arabian shield. The Precambrian rocks of the study area are represented by layered slightly metamorphosed basic and acidic volcanics and the intercalated volcaniclastics. The Tertiary sedimentary is succession of Khulays and Usfan formations rest unconformably on the denudated Precambrian rocks and are composed from bedded mudstones and sandstones. The Tertiary rift-related volcanics are present as a horizontal sheet capping the Tertiary sedimentary succession. The floor of Wadi Qudaid is now occupied by many small villages surrounded by green cultivated private farms. The water supply of the human populations is comping from many wells of the Saudi ministry of agriculture as well as on private wells. Most of the wells are recharged from the loose Quaternary wadi fill (gravels and sandstones). Some wells are deep and recharged from the Tertiary sedimentary succession. During the stormy periods, the private farms in the central part of the wadi become destructed and subjected to abrupt removal as a result of the lateral migration of sheet flood water. The present study confirms normal major and trace elements content of the groundwater of the study area and also the major and trace elements become of low level towards the NE (recharge upstream) part of Wadi Qudaid.

\section{Acknowledgements}

The project was funded by the Deanship of Scientific research (DSR), King Abdulaziz University, Jeddah, under grant No. 351/145/1433. The authors, therefore, acknowledge with thanks DSR technical and financial support.

\section{References}

[1] Italconsult (1976) Detailed Investigations of Wade Khulais Basin. Unpublished Report, Ministry of Agriculture and Water, Riyadh.

[2] Al-Khatib, E. (1977) Hydrogeology of Usfan District, Saudi Arabia. M.Sc. Thesis, I.A.G., King Abdulaziz University, Jeddah.

[3] Al-Hageri, F.Y. (1977) Groundwater Studies of Wadi Qudaid. Institute of Applied Geology, King Abdulaziz University, Jeddah, Saudi Arabia. Research Series No. 2. 132-178.

[4] Jamman, A.M. (1978) Hydrogeology of Wadi an Numan, Saudi Arabia. Unpublished M.Sc. Thesis, Faculty of Earth Sci., King Abdulaziz University, Jeddah.

[5] Al-Nujaidi, H.A. (1978) Hydrogeology of Wade Murawani-Khulais. M.Sc. Thesis, Institute of Applied Geology, King Abdulaziz University, Jeddah.

[6] Al-Gamal, S.A. and Sen, Z. (1983) Quantitative Analysis of Groundwater Quality in Western Saudi Arabia. Proc. Int. Symp. Noordwijkuhout.

[7] Mansour, M.A. (1984) Evaluation of Groundwater Resources of Wade Fatimah by Numerical Model. Unpublished M.Sc. Thesis, Faculty of Earth Sci., King Abdulaziz Uni., Jeddah.

[8] Sharaf, M.A., Farag, M.H. and Gazzaz, M. (1988) Groundwater Chemistry of Wadi 
Uoranah-Alabdiah Area. Western Province, Saudi Arabia, Journal of King Abdulaziz University, Earth Sciences, 1, 103-112.

[9] Al Kabir, M.A. (1985) Recharge Characteristics of Groundwater Aquifers in JeddahMakkah-Taif Area. M.Sc. Thesis, Faculty of Earth Sci., King Abdulaziz Uni., Jeddah.

[10] Basmci, Y. and Al Kabir, M.A. (1988) Recharge Characteristics of Aquifers of Jeddah-Makkah-Taif Region. Mathematical \& Physical Sciences, 222, 367-375.

[11] Alyaamani, MS. and Hussein, M.T. (1995) Hydrochemical Study of Groundwater in Recharge Area, Wade Fatimah Basin, Saudi Arabia. GeoJournal, 37, 81-89. https://doi.org/10.1007/BF00814887

[12] Alyamani, M.S., Bazuhair, A.S., Bayumi, T.H. and Al-Sulaiman, K. (1996) Application of Environmental Isotope on Groundwater Study in the Western Province, Saudi Arabia. Project No. 005/413, King Abdulaziz Uni., Jeddah.

[13] Alyamani, M.S. (1999) Physio-Chemical Processes on Groundwater Chemistry, under Arid Climatic Conditions, Western Province, Saudi Arabia. Project No. 203/418, King Abdulaziz Uni., Jeddah.

[14] Bazuhair, A.S., Hussein, M.T., Alyamani, M.S. and Ibrahim, K. (1992) Hydrogeophysical Studies of Khulais Basin, Western Region, Saudi Arabia. Unpub. Report, King Abdulaziz Uni, Jeddah.

[15] Sharaf, M.A., Al-Bassam, A., Bayumi, T.H. and Qari, M.H. (2002) Hydrogeological and Hydrochemical Investigation of the Cretaceous-Quaternary Sedimentary Sequence East of Jeddah City. King Abdulaziz City for Science and Technology (KACST), Final Report, Riyadh.

[16] Brown, G.F., Jackson, R.O., Bogue, R.G. and MacLean, W.H. (1963) Geology of the Southern Hijaz Quadrangle, Kingdom of Saudi Arabia: Saudi Arabian. Dir. Gen. Min. Res.Misc. Geologic Invest. Map I-210A, 1:500,000 Scale.

[17] Zaidi, S. (1983) Landform and Geomorphic Evolution of Wade Khulais Area. Western Saudi Arabia. Journal of Faculty of Earth Sciences, 5, 153-156.

[18] Zaidi, S. (1984) Geomorphology of Wadi Khulais Area. Journal of Faculty of Earth Sciences, Res. Ser., 18, 98 p.

[19] Moore, T.A. and Al-Rehaili, M.H. (1989) Geologic Map of the Makkah Quadrangle, Sheet 21D, Kingdom of Saudi Arabia: Saudi Arabian. Dir.Gen. Min.Res. Geoscience map GM-107C, 1:250,000 Scale.

[20] Greenwood, W.R., Anderson, R.E., Fleck, R.J. and Roberts, R.J. (1980) Precambrian Geologic History and Plate Tectonic Evolution of the Arabian Shield. Saudi Arabian Directorate General of Mineral Resources Bulletin, 24, 35 p.

[21] Brown, G.F., Schmidt, D.L. and Huffman Jr., C. (1989) Geology of the Arabian Peninsula, Shield Area of Western Saudi Arabia, U.S.G.S Professional Paper 560-A.

[22] Johnson, P.R. (2006) Explanatory Notes to the Map of Proterozoic Geology of Western Saudi Arabia, Technical Report SGS-Tr-2006-4.

[23] Sonbul, A.R. (2010) Hydrochemical Characteristics of Shallow Aquifer in Wadi Qudaid, Western Part of Saudi Arabia. 5th International Conference on the Geology of the Tethys Realm, South Valley University, January 2010, 317-324. 